\title{
THE SOUL (HEART) AND ITS ATTRIBUTES: AN ISLAMIC PERSPECTIVE WITH REFERENCE TO SELF IN WESTERN PSYCHOLOGY
}

\author{
Mohamed Safiullah Munsoor \\ Academy of Islamic Studies. University of Malaya. \\ 50603. Kuala Lumpur. Malaysia. \\ Email: safimunsoor@gmail.com
}

\begin{abstract}
Khulasah
Kajian telah menunjukkan bahawa tumpuan melampau terhadap perkara materialistik dalam kehidupan boleh membawa kepada kecelaruan psikologi yang menyebabkan terhakisnya nilai-nilai sosial yang penting. Kecenderungan terhadap materialistik ini akan menarik manusia untuk menumpukan kepada perkara lahiriah semata-mata, yang sekaligus boleh menghakis pembangunan diri insan yang seimbang. Berasaskan objektif untuk memahami isu pembangunan diri, kajian ini cuba untuk menganalisis perbandingan konsep jiwa dan diri daripada perspektif psikologi Islam dan Barat. Pelbagai sumber rujukan terdiri daripada al-Qur'an, al-Sunnah, dan juga karya-karya penting para sarjana Islam dan Barat telah dimanfaatkan. Dapatan menunjukkan bahawa al-Qur'an dan al-Sunnah mengandungi ajaran yang mendalam mengenai pembangunan spiritual diri manusia. Manakala pasikologi Barat menghuraikan pembangunan diri hanya dari konteks duniawi dan berlandaskan sudut pandang mereka semata-mata berteraskan kaedah yang dibangunkan untuk tujuan tersebut. Dapatan penting dari sudut pandang Islam ialah pembangunan diri membentuk acuan perpaduan dengan akidah; yang menjelaskan tentang sifat jiwa, alat dan kaedah untuk mendisiplinkannya secara mendalam, dengan
\end{abstract}


hanya satu tujuan iaitu untuk bersiap sedia menghadapi kehidupan di akhirat kelak.

Kata Kunci: Jiwa; hati; ilmu pengetahuan; disiplin; pembangunan diri.

\begin{abstract}
It is suggested that the drive for excessive materialistic consumption in every sphere of life is causing an elevation in psychological maladies, with a loss of some key social values. This consumption has accentuated the focus on externalities, while moving away from self-development. With the objective of understanding self-development, this study investigates Islamic and Western psychological viewpoints, with comparisons made of the concept of soul and the self. Multi-sourced referencing of the Qur'an, teachings of the Prophet, as well the analytical works of eminent Islamic and Western scholars, form its methodology. The findings indicate that there is an inner science of self-development that is deeply embedded within the Qur'an and the teachings of the Prophet. Western psychology treats the self in the context of this world and according to its own world view, with methods developed for this purpose. The striking finding in Islam is that selfdevelopment forms an integral part of the fabric of the faith; it has an in-depth exposition of the nature of the soul and the tools and methods to discipline it, all with a view to preparing for the next life.
\end{abstract}

Keywords: Soul; heart; self; knowledge; discipline; self-development.

\title{
Introduction
}

Technology has enhanced the life of people around the world in terms of communication, transportation and availability of goods and services, as well as varied forms of entertainment. This trend, combined with the rapidly changing pace of life, has made humans more dependent on externalities to satisfy their needs. As a result, the 
attention from the inward development of oneself, the inner science or, Islamically, 'tasawwuf', has shifted with the emphasis on the external. This comes at the expense of an internalised state of reflection (tafakkur) embedded within the Prophetic tradition, which is said to lead to a state of peace and tranquility.

This movement away from inward development has resulted in a loss of the meaning of life and alienation from the spiritual pathways to the development. Thus, one witnesses an increase in social ills manifesting as sociopsychological dependencies, including different forms of addiction, as well as a predisposition to states of anxiety, depression and unhappiness. These types of problems have an impact not only on the individual but also societies at large. Seligman ${ }^{1}$, in discussing three kinds of happy life, outlines the good life, that is, those pursuing growth; the meaningful life, where one is in service to things greater than oneself, and the pleasant life of socialising and seeking pleasure. He found that those with a meaningful life felt the greatest positive impact with a high level of satisfaction, followed by the good life and then the pleasant life.

In light of the above, two questions arise: what is the root cause of these social ills and are there related solutions? That is what this study tries to address, albeit in a limited but a meaning way. Consequently, the objective of this study is to examine, predominately from an Islamic perspective, while drawing also from a Western perspective, the key elements of the self (nafs) and the soul, which has embedded within it the heart (qalb). These aspects, including the inter-changeability of the various concepts of the self, soul, heart and spirit are elucidated as the discussion proceeds.

1 Martin Seligman, "Happy People are Extremely Social," in The Psychology Book (London: DK Publishers, 2012), 200-201. 
The methodology undertaken includes firstly attempts to comprehend and gain the required insight into the nature of the self and the soul. This is done through illustrations of its characteristics, while identifying its peculiarities. Secondly, the typology of knowledge is outlined, while simultaneously highlighting the obstacles in its path of self-development. Thirdly, the human mind and its thoughts are outlined, followed by an articulation of the Islamic and the Western psychological perspectives, with relevant conclusions drawn at the end.

The subject of the soul is a perennial one; it both consumes our curiosity and mystifies us. This paper attempts to decipher and understand the soul, the spiritual self and its differentiation from the beastly self, with its accompanying attributes, largely using the body of knowledge as articulated by Abu Hāmid Muḥammad ibn Muhammad al-Ṭūsi al-Ghazāli (1058-1111) in his seminal work Ihyā' 'Ulūm al-Dīn', Shahāb al-Dīn 'Umar ibn Muhammad Suhrawardī (1144-1234) in his 'Awārif alMa ārif, Taqi al-Dīn Aḥmad ibn Taymiyyah ${ }^{4}$ (1263-1328) in his Diseases of the Heart and their Cures, and Ibn Qayyim al-Jawziyyah ${ }^{5}$ (1292-1350) in Spiritual Disease and it's Cure. One eminent and early scholarly work on this subject is by Imam Hārith ibn 'Asad al-Muhāsibi ${ }^{6}$ (781-857), who was one of the forerunners in Islamic tasawwuf (inward science) and a notable theologian, said

${ }^{2}$ Abū Hāmid Muhammad ibn Muḥammad al-Ṭūsi al-Ghazāli, Ihyō' 'Ulūm al-Dīn, Volume III, trans. Maulana Fazul-Karim, 2nd ed. (New Delhi: Islamic Book Services, 1995), 1-351.

${ }^{3}$ Shahāb al-Dīn 'Umar ibn Muhammad Suhrawardī, 'Awārif al-Ma ‘ārif, $2^{\text {nd }}$ Reprint (Lahore: Sh. Muhammad Ashraf, 1991), 1-298.

${ }^{4}$ Taqi al-Dīn Ahmad ibn Taymiyyah, Disease of The Heart and their Cures, trans. Abu Rumaysah (Birmingham: Daar Us-Sunnah Publishers, 2010), 1-102.

${ }^{5}$ Ibn Qayyim al-Jawziyyah, Spiritual Diseases and its Cure, ed. Sheikh Zakariya 'Amiraat (London: Al-Firdous Ltd, 2006), 1-260.

${ }^{6}$ Margaret Smith, Al-Muḥāsibi, An Early Mystic of Baghdad, trans. Margaret Smith (Lahore: Islamic Book Foundation,1935), 1-311. 
to have influenced Imām al-Ghazāli $\bar{i}^{7}$ Related references, including those from Western psychology on the self, with special reference made to Abraham Maslow ${ }^{8}$ and Carl Rogers ${ }^{9}$, are interwoven within the text.

\section{Key Concepts}

Some of the key terms that are defined here are nafs, rūh, $q a l b$ and 'aql. Imām al-Ghazāli, ${ }^{10}$ defines the soul, also termed the heart or qalb, as ' ... that perfect, simple jewellike substance whose only business is recollection, memorisation, contemplation, discrimination and careful consideration, and it accepts all branches of knowledge and does not grow weary of receiving abstract images free of matter. This jewel-like substance or the rational soul (al-nafs al-nattiqah) is the leader of the spirits and the commander of the faculties and all serve it and comply with its command.'

Imām al-Ghazāli ${ }^{11}$ refers to the soul, or an immaterial thing cited as 'latifah', with its attributes. There are scholars who hold the view that there is only one latifah and that is the heart (qalb), while others say that there are five lataif $^{12}$, which have been mapped out, with the qalb (heart) being the key, followed by the rūh (spirit), sirri (innermost conscience), ahkfā (hidden depth) and khāfi

${ }^{7}$ Che Zarrina Sa'ari, Al-Ghazālī and Intuition: An Analysis, Translation and Text of al-Risalah al-Laduniyyah (Kuala Lumpur, Department of 'Aqidah and Islamic Thought, Academy of Islamic Studies, University of Malaya. 2007), 15.

8 The proponent of the famous hierarchy of needs. Abraham Maslow, Towards a Psychology of Being (New Jersey: Martino Publishing, 2011), 127.

${ }^{9}$ The founder of Humanistic Psychology. Carl Rogers, On Becoming a Person: A Therapist's View of Psychotherapy, introduction by Peter D. Kramer (Boston: Houghton Mifflin Company, 1991).

${ }^{10}$ Che Zarrina, Al-Ghazāli and Intuition, 40.

${ }^{11}$ Al-Ghazālì, Ihyyā', 4.

${ }^{12}$ Maulana Allah Yar Khan, Dalael-E-Sulook: An Objective Appraisal of the Sublime Sufi Path (Murshad Abad Mianwali: Idarah-ENaqshabandiah Owaisiah, 1976), 8. 
(most hidden depth). This then becomes the different facets of the soul. They become points of focus for the remembrance (dhikr) of certain Islamic Sufi orders referred to as subtle spiritual organs ${ }^{13}$, which is not necessarily a practice amongst the general body of Muslims.

Imām al-Muhạsibi ${ }^{14}$, in discussing the heart, bases his evidence on the Qu'rān: '... (and when) only he (will be happy) who comes before God with a heart free of evil' ${ }^{15}$ and 'Even so do we (now) cause this (scorn of Our message) to pervade the hearts of those who are lost in sin. ${ }^{16}$ He sees the qalb as the essence of the self, which is immaterial, controlling the conscious nature of man and an instrument, which enables reality to be perceived and interpreted. For the Lord says, 'Have they, then never journeyed about the earth, letting their hearts gain wisdom, and causing their ears to hear? Yet, verily, it is not their eyes that have become blind - but blind have become the hearts that are in their breasts!' ${ }^{17}$ and ' $\ldots$ and men who have hearts with which they fail to grasp the truth, and eyes with which they fail to see and ears with which they fail to hear' ${ }^{18}$. Thus, there is a repeated emphasis in the divine scriptures on the heart, which is a facet of the soul and the seeking of its development.

Skellie ${ }^{19}$ commenting on the various works of Imām al-Ghazāli ${ }^{20}$ states that is it not clear whether he (Imām al-

\footnotetext{
${ }^{13}$ Khan, Dalael-E-Sulook, 61-73.

${ }^{14}$ Smith, Al-Muhasibi, 86.

${ }^{15}$ Al-Shūrā 26:89.

${ }^{16}$ Al-Hijr 15:12.

${ }^{17}$ Al-Hajj 22:46.

${ }^{18}$ Al-A 'rāf 7:179.

19 James Walter Skellie, Al- Ghazāli: Wonders of the Heart, trans. Walter James Skellie (Kuala Lumpur: Islamic Book Trust, 2007) xiii.

20 Al-Ghazālì Ihyā', Ma‘ārif al-Quds fĩ Madārij Ma'rifat al-Nafs, alRisālah al-Laduniyyah and Kimiyā' al-Sa'ādah.
} 
Ghazāli) held the view that the soul was material or immaterial in its nature. He says that some hints alluding to its material nature are found in Kimiy $\bar{a}$ ' al-Sa 'a $\bar{a} a h$; nafs is seen as the vehicle (markab) of the heart; similarly in al-Risālah al-Laduniyyah, the nafs is termed the animal spirit (al-rūh al-haywāni). Skellie ${ }^{21}$ points out that the clearest hint to its material nature is in Mizān al-`Amal, when Imām al-Ghazāli refers to the two meanings of the soul as the animal soul (al-rūh al-haywāni) and the human soul (al-nafs al-insāniyyah). One can argue that this reference of Imām al-Ghazāli applies solely to the immaterial nature of the soul, where analogies and imageries such as 'the vehicle of the heart' are used to capture one's imagination rather than alluding to its material nature.

In discussing the ' $R \bar{u} h h^{22}$ there are two meanings that are alluded to; the first meaning applies to a material thing within the heart, termed the 'life force', which gives the impetus to hear and which vibrates the whole body akin to an electric current. The second meaning is an immaterial and subtle thing, also referred to as the soul that distinguishes life from the lifeless. It is something about which not much is known and when the Prophet s.a.w was asked about it, he referred to the Qur'an, where God says 'And They will ask about (the nature of) divine inspiration (rūh). Say: 'This inspiration (comes) at my Sustainer's behest; and (you cannot understand its nature, $\mathrm{O}$ men since) you have been granted very little of (real) knowledge'. ${ }^{23}$

Like rūh, nafs has two meanings; firstly, it refers to passion or the base, lower self, which embodies greed, anger and other evil attributes. A prophetic ${ }^{24}$ saying

\footnotetext{
${ }^{21}$ Skellie, Al-Ghazāli, xiii.

${ }^{22}$ Al-Ghazāli, Ihyā', 5.

${ }^{23}$ Al-Isrā' 17:85.

${ }^{24}$ Al-Ghazālì, Ihyyā', 5.
} 
captures this: "Truly in the body there is a morsel of flesh which, if it be whole, all the body is whole, and which, if it be diseased, all of it is diseased. Truly it is the heart.' ${ }^{25}$ Secondly, it refers to the situation when the passion has been removed and it assumes different forms as it goes through stages of purification and refinement. This is where the self becomes aligned with the soul or the heart. This will be dealt with in detail in section three below.

To bring some clarity to the over-lapping terms of nafs and rūh, a differentiation is cited which states that the distinction lies in the attributes; when a soul is infused into a child it is the rüh. As life proceeds, as both good and bad traits are acquired and the life becomes associated with the physical body, it is termed the $n a f s^{26}$. Imam Suhrawardi states that $n a \mathrm{~s}^{27}$ is said to have two meanings as follows: i) nafs-i-syai' (the nafs of a thing), which effectively forms the $d h \bar{a} t$ (essence) and the haqiqah (truth) of a thing and ii) al-nafs-al-nătiqah-al-insāni (the human rational nafs), which is also termed the human natural soul.

$A q l^{28}$ likewise has two meanings. Firstly, it refers to the intellect or the medium through which the 'true nature of the material things are known and its seat is in the soul'. Secondly, it alludes to the 'power to understand the secrets of different learnings', where it is termed a subtle essence manifested as knowledge, which is contained within the intellect. These two aspects, one with a material base and the other immaterial, are interdependent. This is reinforced by the hadiths that the first thing that God

${ }^{25}$ Al-Nawāwi, Forty Hadith, $3^{\text {rd }}$ Edition, Hadith no: 6, related by Imam Bukhari and Iman Muslim, trans. Ezzedin Ibrahim and Dennys Johnson-Davies (Damascus: The Holy Qur'an Publishing House, 1977), 42.

${ }^{26}$ Khan, Dalāel-E-Sulook, 59.

${ }^{27}$ Suhrawardi, The 'Awārif al-Ma`ārif, 127.

${ }^{28}$ Al-Ghazālì, Ihyyā', 5. 
created was the intellect ${ }^{29}$. A point of view is that revelation (wahy) comes from the universal intellect, while inspiration comes from the universal soul by a process of emanation ${ }^{30}$. Islam affords a prime place to the intellect, which also includes reason, the ability to discern between right and wrong, good and evil, the real and the illusory, all of which enable man to get nearer to $\mathrm{God}^{31}$. The Qur'ān aptly articulates this: "Say; are those who know and those who do not know equal?" 32 and "The blind and the seeing are not alike, nor are the depth of darkness and the light" 33 , the latter being a metaphor for those who are ignorant or whose hearts are blind.

Imām al-Muhāsibi ${ }^{34}$ cites the verse of the Qu'ran: ${ }^{35}$ "It is God (alone that has this power - He) who causes all human beings to die at the time of their (bodily) death, and (causes to be as dead), during their sleep, those that have not yet died..." This is followed by his citing of Ibn Jurayj, who is said to have stated "The rüh and nafs are in the body of a person, being separated by something resembling a ray of light ..." ${ }^{36}$ Here Imām al-Muhāsibi points out the differentiation between the rüh and the nafs and at the same time their intrinsic link with each other.

${ }^{29}$ Cited in Āl-Ghāzāāi Ihyā', 5. William Chittick says that this hadith is found in many Shi'a hadith texts but in the Sunni tradition it is the sufis who quote it. Cited in William Chittick, Faith and Practice of Islam: Three Thirteen-Century Sufi Texts (New York: State University of New York, 1992), 211.

${ }^{30}$ Che Zarrina Sa'ari, Al-Ghazāli and Intuition, 122.

${ }^{31}$ Frithjof Schuon, Sufism: Veil and Quintessence, A New Translation with Selected Letters, ed. James Cutsinger (Bloomington, Indiana: World Wisdom, 2006), 23.

${ }^{32}$ Al- Zumar 39:9.

${ }^{33}$ Fātị 35:19-20.

${ }^{34}$ Gavin Picken, Spiritual Purification in Islam: The Life and Works of al-Muhāsibi (London and New York: Routledge, 2011), 172-173.

${ }^{35}$ Al- Zumar 39:42.

${ }^{36}$ Gavin Picken, Spiritual Purification, 172-173. 
Al-Attās ${ }^{37}$ sums up the meaning of the four key terms related to the human soul as "... an indivisible, identical entity, a spiritual substance, which is the reality or very essence of man." He adds that this alludes to kamāl, or perfection of being, which is a unifying principle. As Imām al-Ghazālī ${ }^{38}$ states, it has the power to transform something potential to something actual and forms a spiritual entity, termed al-rūhanniyyah, which is created but is in effect immortal, confined neither by space or time. Al-rühāniyyah can be known through the intellect and by means of observing what originates in it ${ }^{39}$. Given that it has varied states, it is called by different names, for example, when it is involved in intellectuality and learning it is termed 'intellect'; when it governs the body it is called the 'soul'. ${ }^{40}$ In a similar vein, when it receives intuitive illumination, it is called the 'heart' and when receiving its own world of abstract entities it is termed the 'spirit' ${ }^{41}$ In this sense, it is manifesting itself in all these different states.

\section{The Structure of the Soul (Nafs) and the Stages of its Development}

\section{i. Western Psychology Perspective}

The notion of self in Western psychology is different from that of Islam, as is evident in the discussion that proceeds. From a behaviorist viewpoint, "the self-concept has an aura of mysticisms not far removed from the concept of

37 Syed Muhammad Naquib al-Attas, Prolegomena To The Metaphysics: An Exposition of The Fundamental Element of the Worldview of Islam, 2nd ed. (Kuala Lumpur: International Institute of Islamic Thought \& Civilization (ISTAC), 2001), 148.

${ }^{38}$ Che Zarrina Sa'ari, Al-Ghazāli and Intuition, 62.

${ }^{39}$ Al-Attas, Prolegomena, 148.

${ }^{40}$ Ibid.

${ }^{41}$ Ibid. 
the soul' ${ }^{42}$ As can be deduced from the definitions cited in Table 1, with the exception of Carl Jung's definition below and his related theories, the concept of self and its development seems to be largely rooted within the worldly realm, in that it is fashioned by how one feels about oneself, as well as what others perceive about you as an individual. There seem to be no concepts or directions connecting one to a spiritual dimension or another life, which Islam embodies.

Table 1 - Multiple definitions of the self in Western psychology ${ }^{43}$ :

\begin{tabular}{|l|l|}
\hline Definitions & $\begin{array}{l}\text { Author-Source } \\
\text { Cited in } \\
\text { Seymour } \\
\text { Epstein } \\
\text { (footnote 36) }\end{array}$ \\
\hline $\begin{array}{l}\text { Self as designated in speech in the first person } \\
\text { singular: I, me, my, mine and myself. It is through } \\
\text { the subjective feeling that the self can be } \\
\text { identified. Linked to the concept of 'looking } \\
\text { glass', where an individual perceives } \\
\text { himself/herself in a way that others perceive } \\
\text { him/her. }\end{array}$ \\
\hline $\begin{array}{l}\text { Expanded on Cooley's definition stating that there } \\
\text { are as many selves as there are social roles, with } \\
\text { some being significant while the others are } \\
\text { specific to particular situations and of minimal } \\
\text { significance. }\end{array}$ & $\begin{array}{l}\text { George } \\
(1934)\end{array}$ \\
\hline $\begin{array}{l}\text { Similar to Cooley and Mead, where the self arises } \\
\text { out of social interaction, where he identified the } \\
\text { self-system as: an organisation of educated } \\
\text { experience called into being by the necessity to } \\
\text { avoid or minimise incidents of anxiety. }\end{array}$ & $\begin{array}{l}\text { Sullivan (1953): } \\
165\end{array}$ \\
\hline
\end{tabular}

42 Seymour Epstein, "The Self-Concept Revisited: Or a Theory of a Theory," American Psychologist, (May 1973), 404.

${ }^{43}$ Ibid., 404-412. 


$\begin{aligned} & \text { Two fundamental approaches, firstly, self as a } \\ & \text { knower, secondly, self as an object of what is } \\ & \text { known. The first proposition was totally rejected, } \\ & \text { while the second was referred to as whatever the } \\ & \text { individual views as belonging to himself including } \\ & \text { the material self (own body, his family and }\end{aligned}$
possessions), the social self (views others hold of
the individual) and spiritual self (emotions and
desires). Self-viewed as having unity and
differentiation and being intimately associated
with emotions as mediated through self-esteem.




\begin{tabular}{|c|c|}
\hline $\begin{array}{l}\text { A self-system, a dynamism that becomes } \\
\text { enormously important in understanding } \\
\text { interpersonal relationships. This dynamism is an } \\
\text { explanatory conception and is not a thing a region } \\
\text { or what not such as superegos, egos, ids, and so } \\
\text { on. }\end{array}$ & $\begin{array}{l}\text { Sullivan (1953): } \\
167\end{array}$ \\
\hline $\begin{array}{l}\text { Self-concept as a self-theory, where an individual } \\
\text { as unwittingly constructed about himself as an } \\
\text { experiencing, functioning individual, and it is part } \\
\text { of a broader theory that he holds in relation to his } \\
\text { entire range of significant experiences. The } \\
\text { fundamental aspects of the self-theory are to } \\
\text { optimise the pleasure-pain balance of the } \\
\text { individual over the course of a life-time; to } \\
\text { facilitate the maintenance of self-esteem, and to } \\
\text { organise the data of experience in a manner which } \\
\text { allows coping with it. }\end{array}$ & $\begin{array}{l}\text { Seymour } \\
\text { Epstein (1971: } \\
407\end{array}$ \\
\hline $\begin{array}{l}\text { Self is defined as ' } \ldots \text { compromising of the totality } \\
\text { of the person, both conscious and unconscious and } \\
\text { is distinct from both the ego and the persona - } \\
\text { conscious aspects of personality.' }\end{array}$ & $\begin{array}{lc}\text { Carl Jung, } & \text { (in } \\
\text { Glassman } & \& \\
\text { Hadad, } & \\
\left.2004: 478^{44}\right) \text {. } & \end{array}$ \\
\hline
\end{tabular}

\section{ii. An Islamic Perspective}

Within Islam, the understanding of the self is inter-linked with its spiritual dimensions, where the concept of nafs in the Qur'an is translated as self or soul. As described by the Qur'an, the nafs traverses three distinct stages in its life; before birth all souls are with God and all souls bear witness that Allāh is their Lord ${ }^{45}$; the stage where our purpose is to worship Allāh ${ }^{46}$, and after death we will be raised up and held accountable for our deeds in this lifetime and we will be either rewarded or punished ${ }^{47}$.

The structure of the human individuality within the domain of Islamic psychology can be comprehended through the three primary elements: nafs or ego-self; qalb

44 William E. Glassmand and Marilyn Hadad, Approaches to Psychology (UK: Open University Press, 2004), 1-247.

${ }^{45}$ Al-A'rāf 7:172.

${ }^{46}$ Al-Dhāriyat 51:56.

${ }^{47}$ Al-Qāri’ah 101:5-8. 
or heart; and $r \bar{u} h$ or spirit ${ }^{48}$. The nafs or self consists of the ego-self, the natural self and the carnal self and it is seen as a complex manifestation linked to the body and intertwined with its pleasure and survival. It has no limit to its desires, be they to its body or personality, where it needs the spiritual self ( $r \bar{u} h)$ to guide and liberate $\mathrm{it}^{49}$.The interconnection between the spiritual self ( $r \bar{u} h)$ and the natural self ( $n a f s$ ) is outlined, where the former needs the latter, in order to 'aspire towards completion, or perfection' ${ }^{50}$. The heart or qalb is captured as the core of our being, the soul, where our deepest and most comprehensive knowing takes place, including its psychic function. A schema of the development of the nafs or self, as derived from Imām alGhazāli's Ihy a ${ }^{, 51}$ and Imam al-Suhrawardi's 'Awārif alMa a arif ${ }^{52}$ with backing from the Qu'rān ${ }^{53}$, is outlined in Figure 1, which follows Table 1 above.

${ }^{48}$ Kabir Helminski, The Knowing Heart: A Sufi Path of Transformation (Boston \& London: Shambala, 1999), 62.

${ }^{49}$ Ibid., 63.

${ }^{50}$ Ibid.

${ }^{51}$ Al-Ghazāli, Ihyā', 5.

${ }^{52}$ Al-Suhrawardi, 'Awārif al-Ma`ārif, 127-129.

${ }^{53}$ Al-Ghazāli, Ihyyā', 4. 
Mohamed Safiullah, “The Soul and Its Attributes,” Afkār 16 (Januari-Jun 2015):

\section{Figure 1 - Stages of Development of the Nafs (Self)}

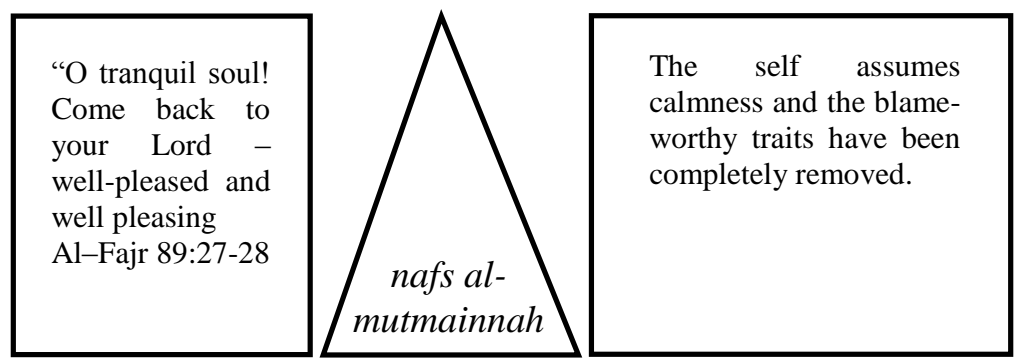

\begin{tabular}{|c|c|c|}
\hline $\begin{array}{l}\text { "And may! I } \\
\text { swear by An- } \\
\text { Nafs } \\
\text { Lawwāmah" }\end{array}$ & $\begin{array}{c}\text { nafs al- } \\
\text { lawwāmah }\end{array}$ & $\begin{array}{l}\text { Al- Hassan Al Basri says } \\
\text { "Verily, by Allah, we } \\
\text { think that every believer } \\
\text { blames himself... } \\
\text { questioning himself..." }\end{array}$ \\
\hline Al-Qiyāmah 75:2 & & $\begin{array}{l}\text { Cited in Tafsir Ibn Kathir, } \\
\text { Vol. } 10 \text {, pg. } 262\end{array}$ \\
\hline
\end{tabular}

\begin{tabular}{|l} 
“...Verily, the \\
(human) self is \\
inclined to evil, \\
except when the \\
Lord bestows his \\
mercy (upon whom \\
he wills). Verily, \\
my Lord is Oft- \\
Forgiving, Most \\
merciful" \\
Yūsuf 12:53
\end{tabular}


It is to be noted that, the knowledge of the soul or psyche is sometimes referred to as Islamic psychology, even though, this field goes beyond this into the metaphysical realm. Thus, in-effect one may not find the answers that one is seeking for since the approach, tools and methods for this purpose may be different from the material sciences.

Moving from the above state of al-nafs al-'ammärah $a l-s \bar{u}$ ' (animal self) to that of the self that is reproachful (al-nafs al-lawwāmah), Imām al-Muhāāsibi ${ }^{54}$ draws an analogy of a beast of burden, which is wild and must be tamed with constant discipline, so that it becomes useful to the master, by which he moves towards the Lord. This is captured as a process, where at this stage the struggle is still going on, with the higher soul gradually beginning to gain the upper hand. This struggle and tribulation continues, until with time, effort and the mercy of the Lord, 'Iblis (satan) and his hosts have been routed and the lusts of the flesh no longer make any appeal; the soul has become a captive, in complete submission to the Will of its Lord' ${ }^{55}$. The self is now at rest and is called al-nafs almutmainnah (see Figure 1), the self at peace with itself and in unison with the soul and all its facets.

\section{Illustrations of the Characteristics of the Soul}

In order to understand the complexity of the soul, Imām al-Ghazāli sketches the soul and its attributes by drawing an analogy of a secret army. This is best illustrated in Figure 2, where the soul at the centre is seen as the King, with its embedded intellect acting as conscience and one's action acting as Ministers who govern. From this, we see that greed and anger both have a role in so far as they maintain their functions well within the limits of feeding

\footnotetext{
${ }^{54}$ Smith, Al-Muḥāsibi, 91.

55 Ibid., 92.
} 
the body and fending off threats, while anger keeps guard to an extent.

Beyond this, both of these traits take over the mindbody function and become detrimental to both the body and mind. As the Lord says, "Hast thou ever considered (the kind of man) who makes his own desires his deity?" 56 This is a strong statement admonishing humans for their greed, which itself is triggered by desires that make them forget God. The Lord goes on to say, "For, unto him who shall have transgressed the bounds of what is right (to the good of his soul), that blazing fire will truly be the goal." ${ }^{57}$

Imām al-Ghazāli ${ }^{58}$ draws an analogy of the soul as an army with an external and an internal eye; the hands, feet, eyes, ears and tongue are the former, and greed for food and drinks is the latter. He then organises these into four divisions: the first, the division of greed, benefits the soul by providing the desire for food and drinks for the up-keep of the body. The second, the open division, uses anger to move the bodily organs to produce the object of greed, namely power and strength. The third division, the senses, with their powers of sight, hearing, smell, taste and touch, are manifested through the five organs to help the human being function properly. The fourth division lies secretly in the brain, generating the power of ideas, thoughts, memories, retention and consolidation.

The analogy that is drawn here defines the importance of both the internal organs and the senses to maintain the equilibrium of the mind-body. Concurrently, it points out that any excesses lead to the dis-equilibrium and harm to oneself. This orientation towards the development of the soul-self is seen in the Qur'an in various places pointing out the dangers of excess. This in

\footnotetext{
${ }^{56}$ Al-Furqān 25:43.

${ }^{57}$ Al-Nāzi'àt, 79:37-39.

58 Al-Ghazāli, Ihyyā', 5-7.
} 
effect forms one of the primary messages for human development.

\section{Figure 2 - Illustration of Some Functionalities of the Soul}

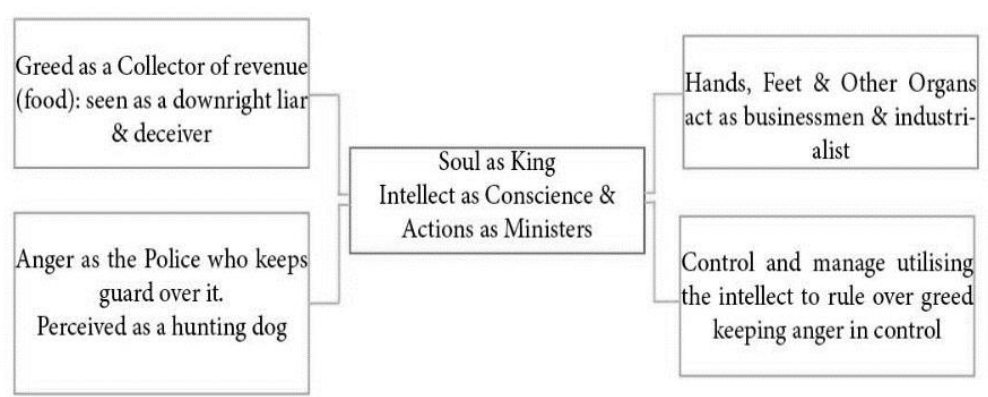

\section{Peculiarities and Types of the Human Soul}

In dealing with the peculiarities of the human soul, Imām al-Ghazāli ${ }^{59}$ illustrates this with some examples. Here each of the bodily organs is outlined and comparisons made in terms of some of the characteristics vis-a-vis particular kinds of animals that have the same traits. When discussing the power of ideas Imām al-Ghazāli ${ }^{60}$ creates a metaphor where the soul is equated to the post office, where all mail is gathered by the senses, that is, accumulated, with the power of thinking as its treasury; the tongue is the interpreter and the five senses are the secret police, each with its own sense or specialty of smell, touch, taste, sight and hearing.

Depending on the situation, the soul can be drawn to the two extreme of good or bad says Imām al-Ghazāli ${ }^{61}$ influenced by the beastly self. For example, when a human exerts himself purely for his physical pleasure or comfort, that is, a hedonistic viewpoint, it can take various

\footnotetext{
${ }^{59}$ Ibid., 10-12.

${ }^{60}$ Ibid., 11.

${ }^{61}$ Ibid.
} 
forms. One's traits can tilt towards the bad, where they become envious like an ox, greedy like pigs, biting like dogs, eating like camels, vengeful like a leopard, cunning like a jackal or clever like a devil. He can also tilt towards the good by exerting his body and mind to worship God, when he becomes like an angel, when God says, "And thus We gave unto Joseph a firm place on earth; and (We did this) so that We might impart unto him some understanding of the inner peace and happenings." ${ }^{62}$

\section{The Soul as a Special Vehicle}

The high stature of the soul is best portrayed in the divine communication, which said, "Verily, We did offer the trust (of reasons and volition) to the heavens, and the earth, and the mountains; but they refused to bear it because they were afraid of it. Ye man took it up..." ${ }^{63}$ The soul was in pre-existence, where God said, "Am I not your Sustainer?" and they answered, "Yes indeed!." Imām alGhazāli says that by virtue of the trust placed in humans, all else has been made subservient to them. This trust he says is Ma rifah, or divine knowledge, and Tawhīd (Oneness).

The objective of purifying the soul is to rekindle the light of divine knowledge, as God says, "Could then, one whose bosom God has opened wide with willingness towards self-surrender unto Him, so that he is illuminated by a light (that flows) from his Sustainer..."65 Imam Haddā $^{66}$ best captures the spiritual journey of the soul when he describes its pre-existence, it then being infused into an infant, where it grows through the life stages until it passes away from this world and goes into the next, with

\footnotetext{
${ }^{62}$ Yūsuf 12:21.

${ }^{63}$ Al-Ahzāb 33:72.

${ }^{64}$ Al-`Arāf 7:172.

${ }^{65}$ Al-Zumar 39:22.

66 -Abdullah Ibn `Alawi Al-Haddād, The Lives of Man, trans. Mostafa Badawi (Aligarh: Premier Publishing Company, 1990), 1-97.
} 
the soul in the Barzakh (Isthmus or intermediate stage), until the day of reckoning. When the screen of sins and obstructions are lifted from the soul, it sees the pictures of the unseen things, where the world of signs and the unseen world unite into Rububiyyah or the presence of God's being, which encompasses everything. There is no existence of anything except of God, His action, His sovereignty. ${ }^{67}$

\section{Disciplining of the Soul and Actions to Get Near to God}

In terms of disciplining the soul or inner self, the Lord then speaks about a reward for those in control thus: "But unto him who shall have stood in fear of his Sustainer's Presence, and held back his inner self from base desires, paradise will truly be the goal!" ${ }^{68}$ The bodily organs, such as hands, the feet and the internal organs all have their respective functions, which keep the body in a state of equilibrium. The soul, with its embedded intellect, acts as ministers controlling and overseeing all related functions, both external and internal, that impact on the mind-body complex (see Figure 2).

It is the servant's duty to purify the soul and make efforts with true and sincere intentions. As Imām alMuhāsibi says, one of the key gateways in the path of man to God, which propels him to divine knowledge, is the 'gate of the intention and its purification, which leads to the will to do good in secret and openly, in things great and small. ${ }^{69}$ The Jibrīl hadīth ${ }^{70}$ lays down a comprehensive framework in Islam, whereby the Angel Jibrīl both asks the questions and confirms the response

${ }^{67}$ Al-Ghazāli, Ihyā'.

${ }^{68}$ Al-Nāzi'āt 79:40-41.

${ }^{69}$ Smith, Al-Muhāsibi, 105.

70 This hadīth was related on the authority of 'Umar ibn al-Khattāb and recorded both in Sahịị Bukhāri and Muslim. An-Nawāwì, Forty Hadith, Hadith 2, 28-30. 
from the Prophet Muhammad s.a.w on the fundamental concepts of Islām, Imān and Ị̣sān.

Relating to Ihssān, the Prophet said "It is to worship Allah as though you are seeing Him, and while you see Him not to know truly He sees you". This has been interpreted in a number of ways, including sincerity of purpose, right action, goodness, charity and also as excellence in whatever one does, especially in worship. This is further reinforced by the Prophetic saying, "Actions are but by intentions and every man shall have but that which he intended..." 71 This in effect forms the doorway to the purification of the soul, thereby directing due attention to God.

The trigger to action is intention and therefore, it is not a case of doing or not doing something unless it is laced with proper intentions and sincerity in purpose. As Imām al-Muḥāsibi says, "Many a man lives his life and dies when his hour comes, without having realised the importance of this." ${ }^{\prime 2}$ The most pertinent prophetic hadīth that has spun several theories and practices is that "Indeed there is in the body a piece of flesh which if it is sound then the whole body is sound, and if it is corrupt then the whole body is corrupt. Indeed it is the heart ..."73, referring to the soul, which is also termed as the spiritual heart.

This is teamed up with the Qur'an injunction where God says, "Verily, God does not change men's condition unless they change their inner ...."74, which calls for ways and means to educate oneself and purify one's heart. Asad refers to this verse as ".. an illustration of the divine law

\footnotetext{
71 This hadīth was related on the authority of 'Umar ibn al-Khattāb and recorded both in Șahịh Bukhāri and Muslim. An-Nawāwí, Forty Hadith, Hadith 1, 26-27.

${ }^{72}$ Smith, Al-Muhāsibi, 105.

${ }^{73}$ Hadith reported both in Sahih al-Bukhari (ng. Trans 1/44/no:49) and Sahih Muslim (Eng. Trans, 3/840/no:3882).

${ }^{74}$ al-Ra`ad 13:11.
} 
of cause and effect (sunnat Allah) which dominates the lives of both individuals and communities ..." ${ }^{75}$ Within this framework and in terms of disciplining one's self, there have been numerous writings, notably including those of

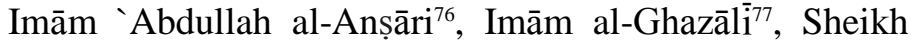
Ibn ${ }^{`} \mathrm{Arabi}^{78}$, Imām ibn Qayyim al-Jawziyyah, ${ }^{79}$ Sheikh 'Abd al-Qādir al-Jīlāni ${ }^{80}$, Ibn Hazm al-Andalūsīi ${ }^{81}$, Imām Sìdi ibn Zarrūk ${ }^{82}$, whose writings can be broadly articulated as follows:

i. Guiding Principles: Concept and principles that guide and orient one towards God.

ii. Morality (Akhlāq): A code of conduct or behaviour that maximises benefits and leads to good, including virtuous characteristics, while excluding blameworthy ones.

iii. A Guide-Teacher: Being in the right company and getting the required guidance to check one's ego

${ }^{75}$ Mohammad 'Asad, The Message of the Qur'ān (Islamic Book Trust, Kuala Lumpur, 2011), 432. Footnote 26 in reference to verse 11, Surah Ar`rad, 13:11.

76 'Abdullah Ansari, Stations of the Sufi Path: The One Hundred Fields: Sad Maydan, trans. and introduced Nahid Angha (Cambridge: Archetype, 2010).

77 Al-Ghazālì, Ihy $\bar{a}$ '.

${ }^{78}$ Muhyiddīn Ibn 'Arabi, The Four Pillars of Spiritual Transformation, trans. Stephen Hirtenstein (Oxford: Anqa Publication in Association with Ibn Arabi Society, 2008).

79 Ibn Qayyim al-Jawziyyah, Spiritual Disease and it's Cure, ed. Sheikh Zakariya 'Amiraat (London: Al-Firdous Ltd, 2006).

80 Abd al-Qādir al-J̄̄lāni, The Removal of Cares (Jala Al-Khawatir): A Collection of Forty-Five Discourses, trans. Muhtar Holland (Kuala Lumpur: S. Abdul Majeed \& Co, 1997).

${ }^{81}$ Ibn Hazm al-Andalūsī, In Pursuit of Virtue: The Moral Theology and Psychology of Ibn Hazm a-Andalusi, with a translation. of his book Al-Akhlaq wa'lsiyar, trans. Muhammad Abu Laylah (London: TAHA Publishers, 1998).

${ }^{82}$ Sidi Zarrūk, The Poor Man's Book of Assistance (California: AlHamra Production, 2001), 16 CDs. 
states and developing oneself, which impacts on the soul.

iv. Methods-Tools: Ways and means of dealing with one's nafs or self at different stages of its development.

v. Supplication (Du'a): Repentance and supplications that evoke one to turn towards the Lord and the proper ways of doing this.

vi. Remembrance of God (Dhikr): Practices and rituals, including prayers, recitation of the divine scriptures and remembrance (dhikr), which deepen understanding of oneself and others.

The eminent physician and scholar, Abū Zayd Aḥmad Ibn Sahl Al-Balkhī (1006-1056), practiced psycho-social healing ${ }^{83}$ because he understood that one's emotional and spiritual state affects one's physiological and physical health. Thus, he combined a code of conduct ('adāb), with philosophy (falāsifah) ${ }^{84}$ to impart ethical training for managing oneself and thereby developing one's soul. There are an increasing number of neuro-science studies ${ }^{85}$ that have identified and discussed the positive impact of these spiritual practices on wellbeing or on the mind-body, which is something to think about seriously in the current context of work-life balance and mental health.

\section{Gaining Knowledge and its Facets}

God says "But as for those who strive hard in Our cause We shall most certainly guide them onto paths that lead

${ }^{83}$ Fathima Abdullah, "Therapeutic Ethics: Managing Anger, Negative Thoughts and Depression According to Al-Balkhi," AKFAR, Journal of 'Aqidah and Islamic Thought, BIL12: Rabi' al-Awwal 1432H ${ }^{84}$ Ibid. (Feb, 2011), 79.

${ }^{85}$ Fathima Abdullah, Wan Abu Bakar Wan Abas and Ng Siew Cheok, Revealing the Scientific Facts of Behind The Act of Salah; Salat Benefits From The Science Perspective (Kuala Lumpur: University of Malaya, 2008). 
unto Us..." ${ }^{86}$ In this light, it is important to understand what keep us from achieving nearness to Him, as well as gaining knowledge about Him. In relation to the soul, five major obstacles stand in the way of gaining knowledge, all of which are cited by Imām al-Ghazāli ${ }^{87}$ thus: i) the natural defect of the soul, ii) impurities owing to greed, passion and low desires (in this regard, the Prophet s.a.w said, "the intellect of a Man who is accustomed to sin goes away" ${ }^{88}$ ), iii) objective of inquiry not being directed towards the soul, where it is be noted that the picture of an object of which a man thinks falls on his soul, iv) the development of a screen between a human soul and a thing desired obstructs its reflection from divine love and grace, v) ignorance: the mode of connection and inquiry though which knowledge is obtained. This, then, refers to the logical or the sequential process of obtaining knowledge.

In terms of differentiating between knowledge and the intellect, there is, says Imām al-Ghazāli ${ }^{89}$, basic, natural and necessary knowledge. Natural knowledge is also termed the preliminary knowledge, which is imprinted on children during their earliest years, while acquired knowledge is gained by learning. Both are termed intellect or wisdom. This can be worldly knowledge, including medicine, science and mathematics. Imām al-Ghazāli makes a very pertinent point that is often confused in present times ${ }^{90}$, where he says religion and science are compatible with each other. He says that religion and science are not opposed to one another and the failure lies in not coordinating the two and not setting up one learning of Sharī'ah (body of knowledge) against

\footnotetext{
${ }^{86}$ Al-'Ankabūt 29:69.

${ }^{87}$ Al-Ghazālì, Ihyyā', 15-17.

${ }^{88}$ Cited in Al-Ghazāli, Ihyā', 15.

${ }^{89}$ Ibid., 19.

${ }^{90}$ Ibid., 20-21.
} 
another. They are in their proper place and thus there is a need to understand them accordingly.

There is also the knowledge that relates to religion and is spiritual in nature. Here the education concerns the soul, God, His attributes and actions. It is important to point out that acquired knowledge, whereby one may study the Qur' an and Sunnah but neither understands them nor acts upon them, can become blind faith (taqlïd). On the other hand, knowledge relating to the intellect is also important but in itself is not sufficient and this needs to be applied and understood says Imām al-Ghazāli. ${ }^{91}$

As indicated above, there are two types of knowledge within the religious domain, namely, wahy or revelation, and ilhām or inspiration. Wahy is cast only upon the souls of the Prophets by Angels while ilham is cast upon the souls of the Prophets and on other personalities and it is not known where is comes from or how it is transmitted. These are knowledge types acquired not through any personal effort. Thus, the soul is a repository of truths and knowledge but the soul's receptivity depends on its state of purity and the obstacles that it faces.

The highest form of knowledge is termed ma'rifah, which is the knowledge of God and the manifestation of divine vision, specifically for the Prophets. For the Lord says about the righteous, "... on the Day when thou shalt see all believing men and women, with their light spreading rapidly before them and on their right..."92 This is further backed up by the statement "... (and) God will exalt by (many) degrees those of you who have attained faith and, (above all,) such as have been vouchsafed (true) knowledge." ${ }^{93}$ This clearly denotes a differentiation between those who have gained knowledge and those who have not, indicating the importance that Islam places on it.

\footnotetext{
${ }^{91}$ Ibid., 20.

92 Al-Hadid 57:12.

93 Al-Mujadālah 58:11.
} 
The soul is like a fortress; frequent attacks are made on it by the devil and therefore it is necessary to safeguard it through its doors, which are made up of the character and conduct of the human being in which it is. In this context, there are twelve doors, of which one must be aware and take care of, states Imām al-Ghazāli $\bar{i}^{94}$ :

i. Anger and sexual passion, when the intellect becomes weak.

ii. Hatred and greed: the Prophet said, "Your love for anything makes you deaf and blind."

iii. Eating with satisfaction: eating to your heart's content or excessive consumption intoxicates the mind and prevents you from prayers, increases your passion, decreases compassion and increases the chance of disease.

iv. Love for fine things: the love for material things leads to its embellishment and the tendency to pay undue attention to it.

v. Dependency on people: the undue dependency on people leads individuals to do things in order to gain the attention of others and seek their favour, which lends itself to becoming artificial. Greed gets into it and becomes the deity.

vi. Hastiness and absence of steadiness: making haste in action and not having a firm resolve leads to disruption. God says, "Man is a creature of haste ..."95, while the Prophet stated, "Hastiness comes from the devil and delay comes from God."

vii. To possess wealth beyond necessity: the more one gets the more one wants and there is no end to it; all time and energy are expended on it and therefore there is no peace of mind.

viii. Miserliness and fear of poverty: this leads to another door, whereby people are prevented from being

\footnotetext{
${ }^{94}$ Al-Ghazālì, Ihyā', 39-42.

95 Al-Anbiyā' 2:37.
} 
charitable, which in turn encourages hoarding and generates greed for wealth.

ix. Staying in bazaars: this is where people while away their time and it consumes them with things that are worldly.

x. Love for sects and hatred for opponents: there is a tendency to hold on to one's sect and develop a hatred for others who do not belong to one's particular sect. This leads to disruption and darkness in the mind, which affects society.

xi. When ordinary men are the leaders of religion: this becomes an issue when those who do not have learning and education and who do not reflect on the mysteries of creation and actions of God lead society. They are not well grounded and therefore they are not able to properly guide people.

xii. Bad opinion about Muslims: this is seen as an issue which has ramifications, whereby people spin their opinions about others causing malice. The Lord says, "O you have attained faith! Avoid most guesswork (about one another) - for behold, some of (such) guesswork is (in itself) a sin..."96

\section{The Human Mind and Thoughts}

The Prophet s.a.w encapsulates the mind and its nature in three examples that he cites. ${ }^{97}$ Firstly, the mind is like a sparrow, which changes every moment. Secondly, the mind is like water in a pot, which changes state when it is heated. Thirdly, it is like a feather in an open field which is turned over again and again. In the light of virtues, vices and doubtful things, the mind takes three forms, as outlined here by both Imām al-Ghazāli ${ }^{98}$ and Sheikh Ibn Taymiyyah $^{99}$ :

\footnotetext{
${ }^{96}$ Al-Hujurāt 49:12.

${ }^{97}$ Cited in Al-Ghazāli, Ihyā', 49.

${ }^{98}$ Ibid., 49-50.

${ }^{99}$ Ibn Taymiyyah, Diseases of the Heart, 41-43.
} 
i. Sound Heart: God-fearing, nurtured by divine service and free from bad conduct. This type of mind is where good thoughts and knowledge are reflected and the Lord bestows his blessings on it, saying, "Those who have attained faith and do righteous deeds incur no sin by partaking of whatever they may $\ldots$ and continue to be conscious of God and to believe, and grow ever more." ${ }^{100}$ This type of mind, which is devoid of blameworthy traits, where the carnal self has been subjugated to the control of the soul. In this state, it is blessed with nine virtues; gratitude, patience, God-fearing, poverty, asceticism, love, commitment, reliance on God, good thoughts and other good qualities and it becomes free from vices and evils. This type of a self is termed al-nafs al-mutmaiinah, where the Lord says, "O thou human being that hast attained to inner peace! Return thou onto thy Sustainer, well-please (and) pleasing (Him) ..."101

ii. Corrupt Heart: A mind full of passions, low desires and other evils. This lends itself to the door to Satan to be opened and for the doors to the angels to be closed. The reference is to a state of mind as stated by the Lord, "Hast thou ever considered (the kind of man) who makes his own passion his deity?"102 This refers to al-nafs al-ammārah bi al-sū' (beastly self), where the self predominates the soul with its darkness.

iii. A Mixed Heart: A mind that is a mixture of good and evil, which vacillates depending on the side towards which it is tilted. It swings between good (or good guidance) and evil deeds (or misguidance). The two forces fight until one of them is triumphant. This can

${ }^{100}$ Al-Mā'idah 5:92.

101 Al-Fajr 89:27-28.

102 Al-Furqān, 25:43. 
be referred to as al-nafs al-lawwämah or the selfcritical self, where there is intense competition between the self and the soul.

\section{Islamic and Western Psychological Perspectives}

There is often confusion in terms of understanding what the soul, the spirit, the heart and the intellect are, given that they are either used inter-changeably or the terms themselves lack clarity. Essentially the term nafs is the concept of self in Islam, which is synonymous with what is called the self in the Western context. The soul and the heart (qalb) are used inter-changeably within the Islamic context. It is important to note that the self can be differentiated, depending on the state of the human being, be he in a beastly or lower state (al-nafs al ammärah bi al$s \bar{u}$ '), a critical or blameworthy self (al-nafs al-lawwāmah) or is evolving to a self of peace (al-nafs al-mutmainnah). In the latter stage, the self has attained purity and in harmony with the soul. These are the general states of spiritual development, where the soul evolves and brings changes to the human self. The concept of the soul in Islam can be seen as a fluid platform in which is embedded the heart (qalb), the intellect, which is interlinked with the heart, with the spirit or rūh energizing it all.

Research in Western psychology, interestingly, resonates with the stages of development of the nafs, where 'possible selves' ${ }^{103}$ are defined as 'ideal selves that we very much like to become, and the selves we are afraid to become' and they can be manifested as evil self, alcoholic self, depressed self, critical self, loving self, etc. Even though there are no spiritual gradations in Western psychology as there are in Islam, as described above, this stratification is important from two viewpoints.

103 Hazel Markus and Paula Nurius, "Possible Selves", American Psychologist (September 1986), 954. 
Firstly, this stratification provides the potential for individuals to change and develop themselves. Secondly, they strata 'provide the essential link between the selfconcept and motivation', to bring about change. Maslow's ${ }^{104}$ theory of self-actualisation of the human being is also indicative of development of the self from a lower state to a more evolved state of being and maturity, what Carl Rogers ${ }^{105}$ calls those who have 'become' or attained 'full-humanness'.

The intellect ( $a q l$ ) can be equated with the rational self (al-nafs al-nātiqah); it is embedded within the soul and its function is to guide the self towards that which is wholesome or good. Not much is known of the spirit (rühn) except that it is from the command of the Lord and acts as the life force or the current of the body and the soul, which in turn animates the body. Ibn Qayyim alluding to the nafs and the rüh brings about some clarity into the discussion when he states that "the difference is in the way of the attributes and not in terms of entity." 106 Thus, they are two names of the same entity, where the distinction lies is in the way of its attributes.

In Islam, the soul, which is contained within the self, but not bound by space and time, is inter-linked with the concept of fitra, which refers to the primordial state of man, one's natural condition and disposition, which is said to be in a wholesome or good state as compared to Christianity, which believes people are born in a sinful state. Man in this primordial state is said to have been witness to and accepted God's covenant through the rüh (spirit), which is from the realm of Allah. Therefore, life

\footnotetext{
${ }^{104}$ Abraham Maslow, Towards a Psychology of Being, 127.

105 Carl Rogers, On Becoming A Person: A Therapist's View of Psychotherapy.

106 In Kitāb ar-Rūh by Ibn Qayyim p. 265 cited in Khan, Dalal-UsSulook, 60.
} 
experience is seen not only as physical but also spiritual, with an innate sense of right and wrong.

In light of the above, the concept of self and its development within Islam cannot be divorced from the spiritual and can only be comprehended within both the worldly and the spiritual domains. Given this, and from a methodological viewpoint, one part of the self - that linked to the worldly domain-lends itself to 'objective' scientific investigation, while the spiritual dimension requires an alternative method, which is beyond the remit of objective-positivistic science but more in the domain of subjectivity-phenomenology. Al-Attās ${ }^{107}$ sums up the Islamic worldview when he states that the focus on worldly ends does not pose an issue in Islam and does not necessarily exclude spiritual aspects; rather, both this world (dunya) and the next (äkhirah) are inter-linked and cannot be separated. In this sense, worldly works, service to people and looking after one's family are seen as spiritual, part of the act of worship.

According to Al-Attas, the qalb (heart) is seen as the mid-point of the psyche, halfway between the nafs (self) and rüh (spirit) and including the subconscious and superconcious faculties of perception, memories and complexes $^{108}$. What is refereed here by At-Attas can be seen as the intellect ( $\left.a q l^{\prime}\right)$, with its related faculties of consciousness, which is embedded within the heart or the soul. The rüh or spirit, referring to the spiritual self or essence, is outlined as an impulse or command of God. It can be a transmitter sending signals to the heart, with it having some key servants including reason, reflection and conscience. The development of the individuality or the totality of a person results from the inter-relationship

107 Al-Attās, Prolegomena, 21-22.

108 Al-Attas, Prolegomena, 63. 
between the three above-mentioned dimensions, namely, the heart (qalb), spirit (rūh) and the self (nafs) ${ }^{109}$.

Imām al-Muhāsibi ${ }^{110}$ describes ongoing internal dynamics, where the higher nature of man constantly struggles with the lower self (nafs), which urges it to pass through the gateway of the senses, "the seat of the appetites and of passion, the "flesh", with its sinful lusts'. In a similar vein, Ibn 'Arabi ${ }^{111}$ in his Divine Governance of the Human Kingdom, encapsulates the inner struggle when he states: "The conflict between reason and the evilcommanding self is caused by their very nature, which induces each of them to try to dominate the whole of the human being and to be the ruler of it. Even when one of them is able to conquer the whole realm, the other still strives to regain what it has lost and to repair what has been destroyed. This swing between the two opposing states forms the consciousness of humans, whereby transcending the evil-commanding self forms the very essence of the spiritual journey."

The Prophet s.a.w characterised the best man as the one whose soul is God-fearing, a concept called 'taqwa', where there is no deceit, no deception, no treachery, no contrivance and no hatred. For God says, "Consider the human self, and how it is formed in accordance with what is meant to be and how it is imbued with moral failings, as well as with consciousness of God. To a happy state shall indeed attain he who causes this (self) to grow in purity, and truly lost is he who buries it (darkness)." 112 The inference that can be made from all of the above is that the soul is a special vehicle, which we need to look after, so

\footnotetext{
${ }^{109}$ K. Helminski, The Knowing Heart: A Sufi Path of Transformation, (Boston \& London: Shambala, 1999), 64.

${ }^{110}$ Smith, Al-Muhāsibìi, 90.

${ }^{111}$ Helminski, The Knowing Heart, 65.

112 Al-Shams 91:9-10.
} 
that it gets enlightenment and can carry us well in this world and the next.

The success of a human being depends on the framework that is inculcated by the individual, where God's vision become the ultimate goal, this world being a temporary place and the next world a permanent abode, with the body as a carrier and the limbs as servants. Thus, human beings can enlighten their souls, where "God is the light of the heavens and the earth. The parable of His light, as it were, that of a niche containing a lamp; the lamp is (enclosed) in glass, the glass (shining) like a radiant star; (a lamp) lit from a blessed tree - an olive-tree that is neither of the east nor of the west the oil whereof (is so bright that it) would well-neigh give light (of which) even though fire had not touched it; light upon light..."113, or darken like a fathomless sea, depending on the route they choose. Thus, the prime purpose in Islam is to purify oneself from the blameworthy traits, where the self becomes more akin to the soul-heart and is propelled towards gaining this light and moving towards God.

There are many actions that will increase the nearness to God and enhance the flow of light. These include asceticism, full freedom from worldly connections, full direction of their energies to God, cutting out all worldly connections (make it vacant for God), restrict efforts on worldly things, perform compulsory and optional duties and sit in prayer, recitation and meditation with thoughts centered on the One being. The soul is the medium which absorbs both light and darkness according to one's intentions and action and in this regard Imām alGhazāli $\bar{i}^{114}$ points out that the vision of the soul is through the subtle essence or latîfah by which spiritual things are seen, where "...it is an immaterial thing or formless lațïfah or basic subtle element which has got connections

\footnotetext{
113 Al-Nūr 24:35.

114 Al-Ghazālí, Ihyā', 4.
} 
with the material heart ... it catches the knowledge of God and spiritual world. It is punished and rewarded." This can take the form of dreams or it can be in a wakeful state. In referring to the blindness of the soul, God says "... for whoever is blind (of heart) in this (world) will be blind in the life to come (as well)." ${ }^{115}$ The Lord refers to the sight of the soul when He says, "The servant's heart did not give the lie to what he saw..." $" 116$. This is reinforced by what God said, "...We gave Abraham (his first) insight into (God's) mighty dominion over the heavens and the earth ..."117

There are different streams of knowledge, namely that concerning the intellect and that concerning religion. For the salvation of the soul, the intellect, despite being necessary to discern things, is insufficient on its own and in this regard, anyone applying blind faith (taqlīd) without the intellect is a fool, while anyone relying only on the intellect without divine guidance is a proud person. ${ }^{118}$ Thus, the two strands should be woven together. Imām alGhazāli likens the intellect to food and religious education to medicine, where both are necessary for a healthy body. In a similar vein, for a diseased soul, the medicine of the Shari'ah in terms of the duties as prescribed by the Prophet s.a. $\mathrm{w}^{119}$ is a necessary ingredient for its sickness.

The transmission of knowledge of the soul takes three forms, namely, the prophecies of the Prophets (wahy); ilhām-kashf (inspiration) and the whisperings of the devil (waswās). An important distinction is presented, whereby thoughts are divided here into good and bad. The state of the soul is thus captured: "... the soul changes from one condition to another. This effect on the soul is

\footnotetext{
${ }^{115}$ Al-Isrā’ 17:72.

116 Al-Najm 53:11.

117 Al-An 'ām 6:75.

118 Al-Ghazāli, Ihyā', 20-21.

${ }^{119}$ Ibid., 21.
} 
called khawattir and out of it there grows will and then intention." ${ }^{20}$ Knowledge in the above light can be seen as being bi-polar along a continuum, where for example things can be good-bad in varying degrees. As a general axiom, there are always two aspects to things in nature, the exception being God, who is One.

Having presented an exhaustive list through which one can be misled, Imām al-Ghazāli $\overline{1}^{121}$ advises what can drive away the devil "when the devil which is like a hungry dog comes to your door, fill yourself with constant dhikr or remembrance of God; when the soul is heedless of remembrance, the machination of the devil comes in." This means that whatever thoughts and actions one may have or do, it is necessary to stay focused on the Lord, so that the devil cannot seep into your soul. Focusing on the here and now, or a state of mindfulness, has now become a form of meditative practice that has an impact on the brain and well-being of individuals. ${ }^{122}$

The difference between that and Islam is that in Islam it is not mindfulness for mindfulness' sake but the focus on the One, the Intelligence and the Supreme. It is recommended that one recites a verse from the Qur'an titled Ayat al-Kursi $\bar{i}^{123}$ the verse of the throne, which drives away the devil. Imām al-Ghazāli points out "... clear your soul first from passion and greed and then take the medicine of $d h i k r$. When $d h i k r$ enters such a heart which is free of thoughts other than God, the devil flees away from it, as disease goes away ..." The other aspect is supplication to God, where He says, "And If My servant ask thee about Me behold, I am near; I respond to the call of him who calls ..."

\footnotetext{
${ }^{120}$ Ibid., 32-33.

${ }^{121}$ Ibid., 42-44.

${ }^{122}$ Mark Williams, Oxford Centre for Mindfulness, accessed March 2, 2015, http://oxfordmindfulness.org.

${ }^{123}$ Al-Baqarah 2:255.

${ }^{124}$ Al-Baqarah 2:186.
} 
It is pertinent to quote a Cherokee native Indian narrative ${ }^{125}$, which is spiritual in nature and captures the inherent attributes of the self and how we choose to be either good or bad. As outlined here, this resonates well within the context of Islam.

An old Cherokee is teaching his grandson about life: "A fight is going on inside me," he said to the boy. "It is a terrible fight and it is between two wolves. One is evil he is anger, envy, sorrow, regret, greed, arrogance, selfpity, guilt, resentment, inferiority, lies, false pride, superiority and ego." He continued, "The other is good he is joy, peace, love, hope, serenity, humility, kindness, benevolence, empathy, generosity, truth, compassion and faith. The same fight is going on inside you - and inside every other person, too." The grandson thought about it for a minute and then asked his grandfather, "Which wolf will win?" The old Cherokee simply replied, "The one you feed."

\section{Conclusion}

The subject of the soul and its attributes is a vast subject that cannot be comprehended within one paper and what is dealt with here is only an insight into it. It is, however, found that the inner science of the development of the self (nafs) is deeply embedded within the Qur'an as well as in the sayings of the Prophet; it is a guide to mankind on how to develop oneself. The most striking feature of the soul, which is embedded within the human self is its propensity to good and evil depending on which side you nurture, the potential to become a saint or a sinner. The soul is a complex entity and, as the Qur'an has articulated, only a little knowledge has been vouchsafed to us.

From the little that we understand, it seems that the soul has multiple functions in the way it governs itself and

\footnotetext{
125 Cherokee Indians, Cherokee Legend - Two Wolves, accessed October 17, 2013, http://www.firstpeople.us/FP-HtmlLegends/TwoWolves-Cherokee.html.
} 
it appears that the intellect ( $a q l$ ), which is embedded within it, guides it in terms of decisions made, while the heart (qalb), which is part and parcel of the soul, has its active cognition and ability for empathy, is seen as an intermediary between the soul and the spirit, all encompassed within one framework. The rüh, or the spirit, is seen as a radiant light that animates the body and is akin to the electricity that keeps things alive, that is, the life force. There is a clear distinction between the notion of soul in Islam, and the Western psychological perspective; in the former, in Islam, the soul or the heart which is used inter-changeably is from God and serves one both in this world and the next life, while according to the Western perspective the self, as it is called, is confined to this, material, life.

Within the Islamic framework, as outlined in the Divine's words, there are stages in the development the self (nafs), from an animal or beastly self (al-nafs alammārah bi al-sü'), to a self that is blameworthy or has developed a level of awareness (al-nafs al-lawāmmah), to a more stable state of being at peace with oneself and the Lord (al-nafs al-mutmainnah). As the self becomes more purified and virtuous, then it integrates with the soul-heart and establishes more intimate connection with God, from whose domain it originated.

In order to travel through the various stages, there are methods and tools embedded within the acts of worship, as well as in having good morality (ahklāq), which is manifested in a courteous code of conduct. There is thus an 'inward science' within Islam, which enables the development of the self in preparation for life in this world and, more importantly, in the next world. Thus, the soul's purpose is to produce not only an altered state of consciousness but also a deeper comprehension of God as 
the Creator and Sustainer of the universe. ${ }^{126}$ The Prophet s.a.w portrayed Islam as a 'middle-way' (ummatan wasatan) and in this light Imām Khwāja Kamāl al-Dīn says, "It is not the killing of human passion which makes high morality, but the balancing of them to certain measures, which creates healthy morals and produces spirituality." 127 Islam recognizes that there is a role that passion does play in sustaining the human life especially in terms of its nutrition and reproductive roles. The focus in Islam is overcoming the beastly self, which predisposes one to connect with God.

On the other hand, within the context of Western psychology, there is the self and its development, what Maslow called the progression towards self-actualisation or, as Carl Rogers calls it, full-humanness. There appears to be no concept of the soul in Western psychology, as in Islam or in the Judeo-Christian tradition; rather, the self seems to be anchored very much in this material world and the preparation is only in the light of this world and not the next life. There are tools and methods within Western psychology, which ranges widely from cognition and behaviour therapies to people-centred therapy. Most recently, spiritually-oriented practices have been incorporated into these therapies, including mindfulness and meditation, thus reinforcing some of the traditional and spiritual methods used within religion.

The Islamic framework outlined above illustrates a rich tradition for self-development. Given that the focus within Islam goes beyond this life and into the after-life, the methods of self-development appear to be an integral fabric of the faith, which is rigorous and time-tested by

126 Malik Badri, Contemplation: An Islamic Psychospiritual Study, trans. Abdul-Wahid Lu'Lu'a (Herndon, Virginia: International Institute of Islamic Thought, 2000), 1-2.

127 Khawaja Kamal-Ud-Din, "The Threshold of Truth", in Higher Studies in Islam Series 1, (London: The Basheer Muslim Library, 1923), 80. 
scholars and sages. Thus, these methods are thought to be highly beneficial within the context of current society in shifting attention from the extrinsic to the intrinsic self, for real change can come only from within.

\section{References}

Al-Ghazālì, Abū Hāmid Muhammad b. Muhammad alṬūsī. Wonders of the Heart, trans. W. J. Skellie. Kuala Lumpur: Islamic Book Trust, 2007.

Al-Ghazālì, Abū Ḥāmid Muḥammad b. Muḥammad alṬūsī. Ihyā' Ulūm-Id-Dìn, Volume III, trans. M. F. Karim. New Delhi: Islamic Book Services, 1995.

Al-Andalūsi, Ibn Hazm. In Pursuit of Virtue: The Moral Theology and Psychology of Ibn Hazm a-Andalusi, with a translation of his book by Al-Akhlaq wa'lsiyar. London: TA-HA Publishers, 1998.

Al-Attas, S.M.N. Prolegomena to the Metaphysics: An Exposition of the Fundamental Element of the Worldview of Islam, $2^{\text {nd }}$ ed. Kuala Lumpur: International Institute of Islamic Thought \& Civilization (ISTAC), 2001.

Al-Haddād, Ibn `Alawi Abdallah. The Lives of Man, trans. M. Badawi. Aligarh: Premier Publishing Company, 1990.

Al-Jawziyyah, Ibn al-Qayyim. Spiritual Disease and its Cure, ed. Sheikh Zakariya. London: Amiraat Al-Firdous Ltd, 2006.

Al-Jīāni, `Abd Al-Qādìr. The Removal of Cares (Fala AlKhawatir): A Collection of Forty-Five Discourses, trans. Muhtar Holland. Kuala Lumpur: S. Abdul Majeed \& Co, 1997.

Al-Suhrawardi, Shahab-u'd-Din 'Umar b. Muhammad. The 'Awarif-ul-Ma'arif, trans. H. Wilberforce Clarke. Lahore: Sh. Muhammad Ashraf, 1991.

An-Nawāwì. Forty Hadith, trans. Ezzedin Ibrahim and

Dennys Johnson-Davies, $3^{\text {rd }}$ ed. Damascus: The Holy Qur'an Publishing House, 1977. 
Ansari, Abdu'illah. Stations of the Sufi Path: The One Hundred Fields: Sad Maydan, trans. Nahid Angha. Cambridge: Archetype, 2010.

Badri, Malik. Contemplation: An Islamic Psychospiritual Study, trans. Abdul-Wahid Lu'Lu'a. Herndon, Virginia: International Institute of Islamic Thought, 2000.

Cherokee Indians, Cherokee Legend-Two Wolves, http://www.firstpeople.us/FP-Html-

Legends/TwoWolves-Cherokee.html.

Fathima Abdullah, 'Therapeutic Ethics: Managing Anger, Negative Thoughts and Depression According to AlBlkhi', AKFAR, Journal of 'Aqidah and Islamic Thought, BIL12 (Feb, 2011): 79.

Glassman, W.E. and Hadad, M. Approaches to Psychology. United Kingdom: Open University Press, 2004.

Helminski, K. The Knowing Heart: A Sufi Path of Transformation. Boston \& London: Shambala, 1999.

Ibn 'Arabi, Muhyiddīn. The Four Pillars of Spiritual Transformation, trans. Stephen Hirtenstein. Oxford: Anqa Publication in Association with Ibn Arabi Society, 2008.

Ibn Taymiyyah, Taqi ad-Din Ahmad. Disease of the Heart and their Cures, trans. Abu Rumaysah. Birmingham: Daar Us-Sunnah Publishers, 2010.

Kamal-Ud-Din, Khawaja. The Threshold of Truth, Higher Studies in Islam Series 1, The Basheer Muslim Library, The Islamic Review Office, The Mosque, Working, London, 1923.

Khan, M.A.Y. Dalael-E-Sulook: An Objective Appraisal of the Sublime Sufi Path. Pakistan: Idarah-ENaqshabandiah Owaisiah, 1976.

Markus, H. and Nurius, P, "Possible Selves," American Psychologist, (September 1986): 954.

Maslow, A. Towards a Psychology of Being. New Jersey: Martino Publishing, 2011. 
Picken, G. Spiritual Purification in Islam: The Life and works of al-Muhasibi. UK: Routledge, 2011.

Sa'ari, C.Z. Al-Ghazālī and Intuition: An Analysis, Translation and Text of al-Risalah al-Ladunniyyah. Kuala Lumpur: University of Malaya, 2007.

Schuon, Frithjof. Sufism: Veil and Quintessence, a New Translation with Selected Letters, ed. James Cutsinger. Indiana: World Wisdom Publication, 2006.

Seligman, Martin. "Happy People are Extremely Social." In The Psychology Book. London: DK Publishers, 2012. Seymour E. "The Self-Concept Revisited: Or a Theory of a Theory," American Psychologist, (May 1973): 404.

Sidi Zarrouk. The Poor Man's Book of Assistance. California: Al-Hamra Production, 2001.

Smith, Margaret. Al-Muhasibi, an Early Mystic of Baghdad, trans. Margaret Smith. Lahore: Islamic Book Foundation, 1935.

Syed Masood-ul-Hasan and Ibrahim M. Kunna, ed. 110 Ahadith Qudsi: Sayings of the Prophet (s.a.w). Riyadh: Darussalam, 2006.

Williams, Mark. Oxford Centre for Mindfulness, http://oxfordmindfulness.org. 